\title{
寄在 \\ イゴール・I・シコルスキーの足跡
}

\section{まえがき}

Dr. Igor I. Sikorsky は昨年の当学会春期講演会で ヘリコプタの発達について特別講演を行い，その業繢 を物語る歴史的なスライドを上映した，彼がヘリコプ 夕技術に抢ける第一人者であることはあまねく人の知 る所であるが，その前に飛行機特に大形商用飛行機の 開拓者であったことを考えると，正に世界航㘹史上の 巨人と呼ぶに相応しい人物てある. 彼は始めから手軽 なVTOL と大形豪華な旅客機の創造を目ざし，年代 的には別々にその両者を実現して行った，彼の構想は 常に時代をはるかにリードしたが，それを実現するた めの技術的手法は漸進的であった，後の点ではユンカ ースやロールパッハに一ちゅうを輸するが，それは彼 の業績の光をいささかも鈍らすものではない，彼の本 領は理論や解析を駆使した研究にあるのですなく，た だ勇敢な実行家肌でもなく，真理を速く正しく把握し， かつ独特の直観によって知識の新分野を開拓し，それ を合理的な方法でチェックした後実行するに敏で，常 に理論が彼の後を追いかけて証明して行ったという印 象をうける. この事は科学を本当に理解する人にして 始めて可能なことて，開拓者に共通の特徽といっても よかろう. 彼の講演の前に彼の略歴が紹介されたが， 今回本学会誌に揭载される機会に彼の自叙伝“The Story of the WINGED-S”を熟読して感銘を改め, 如何に压縮したらよいかに非常に苦心した. 彼は自叙 伝の中に特に章を設けて“開拓者の業績”“神秘的 な機能一直観”“航空の将来”を語り，また所々に 彼の人類社会観や機械文明論の片鱗を述べているのは 興味樑いが，ここに紹介できないのは残念である. 以 下述へる略歴業綪中に出てくる航空機の要目は, 古い ものはほとんど Jane の年鑑によった. ヘリコプタの 名称，重量，性能は民用型と軍用型で異なるが，一般 には民用型を採用し，必要に心じて軍用型に触れた。

\section{第 1 期}

彼は 1889 年ロシヤのキエフで, 心理学教授の息子 として生れた. 海軍兵学校に在学中, その頃欧洲での 機械文明の勃興に刺战されて，創造的な技術に一生を

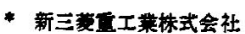

堀 越 二 郎**

挥げる望みを抱き，同校を中退してパリに赴き，半年 ほど 1 人の師について工学を学び大いに得る所があっ た. 1907 年キェフの工科大学の機械工学科に入った が, 理論や高等数学には余り興味が涌かず, 1908 年 の要休みに父に伴われてドイッを訪れた際，初期のッ エッペリン飛行船とライト兄弟の飛行について始めて やや精しい新聞記事に接し，彼等の仕事の意義を感得 するとともに，自分の生涯は空にありと決心し，しか もその最初の方向をへリコプタにきめた. 1909 年当 時の欧洲の航空界の中心となっていたパりを再訪し， そこで後に航空界に名を成した Bleriot や Feber 等 に会い，航空に関する知識をできる限り吸収し，その 直後 Bleriot が海峡横断に成功して名声を上げた単葉 機に䔩備されたのと同ヒアンザニ空冷 3 気篇 25 馬力エ ンジンを買求め，パリての先非達の忠告に反いて初志 通りヘリコプタの製作を始めるへくキエフに帰った。

彼の最初の航空機一2 重反転式へリコプタ（写真 1) 一は 1909 年夏完成したが，馬力不足のため高さ数 $\mathrm{ft}$

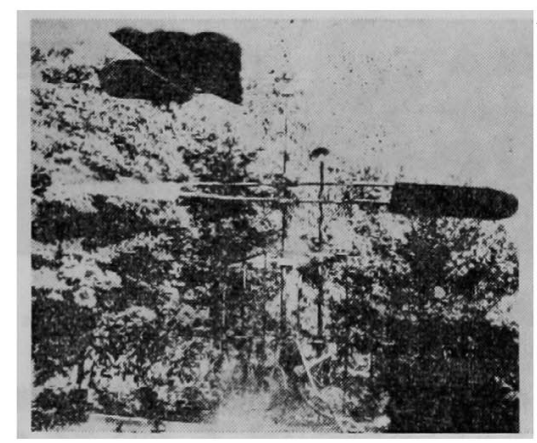

写真 1 第 1 号へリコプタ

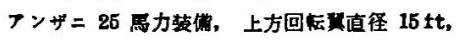

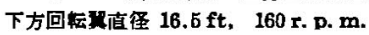

のジャンプ以上浮揚せず，特に方向操獭に困って中止 し，パリを三度目に訪れて先輩達から示唆を得ようと した. ところがフランスにおける飛行機の進歩に感銘 し,ここで彼の関心はようやく飛行機に向った. 当時 は飛行のパイオニアにとってはロマンチックというへ き時代で，その後もしばらくは空気力学や操綎法を系 統的に教之得る人は皆無で, 各自が自らの経験で学ふ より外ない時代がつついた。 
1910 年春前と同じエンジンを装備した第 2 号へリ コプタ (2 重反転式) と並行に, アンザニ 15 馬力を 装備した彼の第 1 号飛行機 S-1 を試作したが，両機 とも馬力不足て浮揚不可能, ついに 5 月ヘリコプタの 研究の方は断念した.

第 2 号飛行機 S-2 (写真 2) は 1910 年 5 月末完成, 6 月 3 日約!180 m の飛行に成功した.

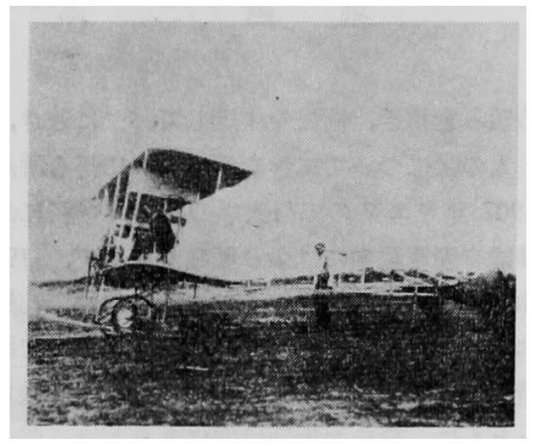

写 真 2

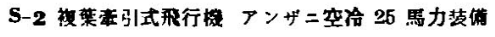

1911 年第 5 号の S-5 で始めて $1,000 \mathrm{~m}$ 以上の高 度を自由に飛へる飛行機を得たが，1911 年秋完成し た S-6 の成績は芳しからず，解体してその部品を利 用し, 彼独特の方法で空気抵抗测定を行った結果を取 スれて各部を改良し，その年の暮 S-6-A（写真 3）を

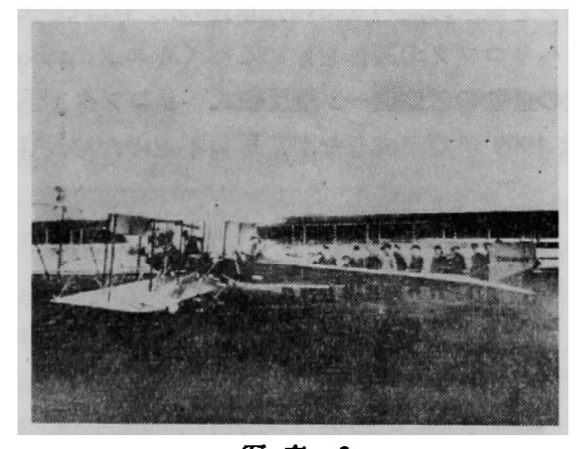

写真 3

S-6-A 被菜率引式, アーガス水冷 4 匃策 100 昌カエン

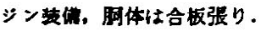

完成した.この時からようやく彼にとって飛行機は道 楽から労力と心配の対象に変った. 1912 年春 S-6-A はモスコー航架博て最高賞を,さらにこれを洗練した S-6-B は陸軍飛行競技会で 1 等赏を獲, 数機の注文を 其った. S-6-B の最大速度は $113 \mathrm{~km} / \mathrm{h}$, 速度と樌载 量は当時ロシャで最高であった。

1912 年春彼の航空機事業の第 1 期一ロシヤでの活 動一を決定する事件が起ったすすなわち， S-6-A と その改良拉よび今後 5 カ年の航空機に関する一切の発 明権利提供の代供に，体給，ローヤルティおよび 1 年 に1機以上の新形機の陚作をやらせてくれるという条 件で，ロシヤ・バルチック銠道車轌会社の分工場とし
て設立された航空機工場の技術主任となった（今まて のキェフでの協力者のうち6 人も彼に従って入社).

1913 年 5 月 S-9 Grand 昂が完成した，本機はその 大きさ，4発飛行機という点および操維席と客席か大 形の空をもつキャビンになっていた点で世界最初，ま た大形旅客機としての彼の，かつ世界の第一弾でっ た. 彼は設計に当り, 主翼の縦横比の効果を彼独特の 推諭によって党り，また大形の創造物は飛べないとい う一般の説を反証する計算を行い，初飛行後プロペラ の離陸時効率を向上するため，2 基ずつ串形配列であ
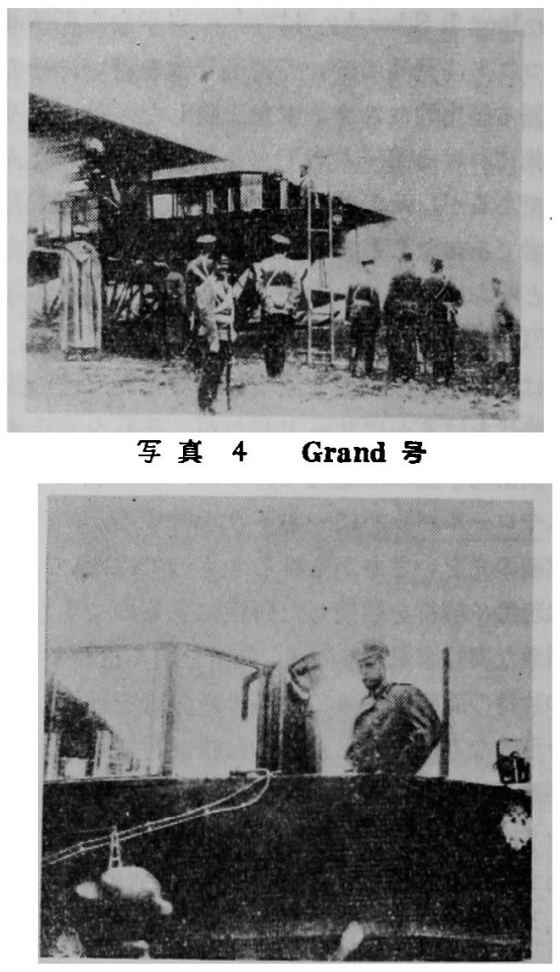

写真 5 Grand 号

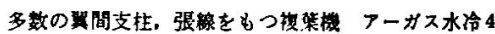

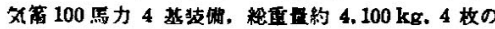

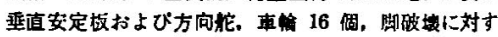
る保安のため数組のスキーを湖えていた。

ったエンシン䒾備を並列に改めた，5月初飛行，どの

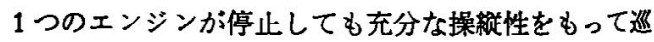
航でることが立証された，7月皇帝ニコラス2世が 視察したが，彼は皇帝が技術上の素盖が相当あるのに 第いた．写真 4 および 5 はそ，の時の光累て，写真 5 の ハルコニー上の人物は彼と皇帝である.その年 8 月 8 人を乗せて 1 時間 55 分の世界耐空婄録を作った。

1913 年夏 S-10 (被葉), S-11 (単葉) の 2 種の軍 用機を試作， S-10 改良型は軍の注文により数機製作 された。

1913 年末 Grand 号と同ビンジを装備し, やや 大形化し，胴体および翼の形の改良，翼間隔の增大等 
による空力的洗練，厇い客宝の後に赛台，小卓を容れ た私室まで㒂えた京華な 4 発旅客機 Ilia Mourometz （写真 6）が完成した。風車発電機により龟灯をつけ,

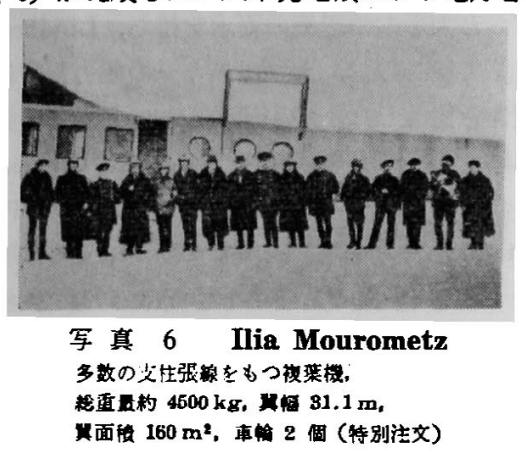

客室はエンジンの排気により暖房していた. 1914 年 2月 16 人の客を乗せた飛行に世界最初に成功し， 1 又は 2 基のエンジンが停止しても飛行統可能, 改良 すべき絊はあるにしても，旅客機として実用し得る との自信を持った． 5 月 12 人を乗せて $2,100 \mathrm{~m}$ ま で上㫒して大形機に対する俗説を反証し，6月7人の 客を乗せて 6 時間 33 分の世界耐空記録を作り，また 6 月末ぺトロプラード・キエフ往復飛行の途中，世界て 初めて機上で卓を囲んだ正式の食事をとった，7月底 の平らなフロートを装置し, 水上発着を成功裡に行。 た. 陸軍は 10 機の注文を与え，彼と会社を喜ばせた．

1914 年 7 月 20 日第一次大戦勃発し, 彼は Mourometz の軍用への改設計，兵装装着改修，軍パイロッ トの訓練（その時彼は 4 発機を離着操綐でる恐らく 世界て唯一人であった）に䎲殺され，工場は3交替 24 時間制て倠いた． Mourometzは戦線に駆り出された が高度不足て役立たないことが判った．第 3 番機 Military Ilia Mourometz はエンシンを强化（内側 140 馬力, 外側 125 馬力) し, 胴体も縔重量䈹少 したかいがあって，全装備て $3,000 \mathrm{~m}$ まて上昇でき た. 彼の工場の主宰者および彼の意見具申によって本 譏の一隊が編成され，1915 年 2 月から 2 力年ほど，

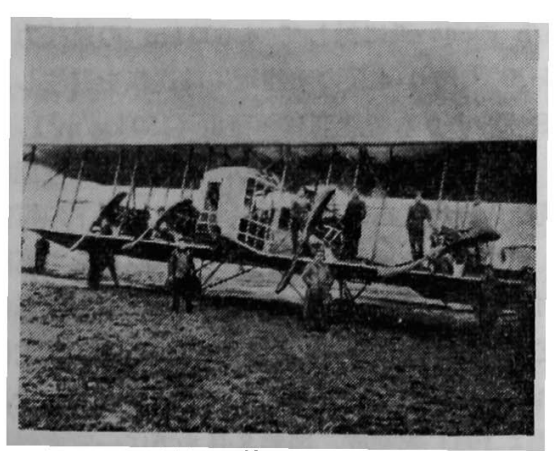

写真 7 最終型 “Ilia Mourometz E”

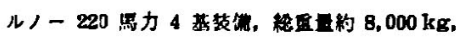

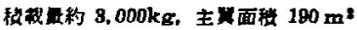

東部戦線で爆撃，值察行動に従い，世界のこの級の軍 用機の中て最も成功し， 1917 年表革命勃発による休 戦まてに合計約 75 機納入された. その間燃料タンク のさくれつ弾に対する防火対策, 戦閂機の追尾攻撃に 対する尾部銃手席追加，エンシンの強化，機体の大型 化，エンジン国産化等が行われた.

\section{第 2 期}

赤色革命の暴状を目のあたり見た彼はこれに望みを 絶ち, 1918 年 3 月単身イギリスにのがれ，直ちに パリに渡り，連合軍のため $1,000 \mathrm{~kg}$ の爆弾を積み 得る爆學機の設計を 委啒された，設計図ができ上る 須休戦となり，しばらく滞仁したが，欧洲で航空に 関する職を求めることに見切りをつけ，世界て航空輸 送が最先に開けそうな土地，個人の自由と創造性を最 もよく認める国アメリカに 1919 年 3 月度った. しか しここも戦後航空事業は衰微し，努力む空しく彼の希 望の仕事は見つからなかった．䏠年ニューヨークで主 にロシヤ移民に理科，数学などを教える夜学校の教師 となり，しばしば付近の小ク゚ループに招かれて航空， 天文などについて講演した，彼の生徒および講演を間 いた人の中に、次第に彼の能力, 熱情の理解者が增し, ついに 1923 年 5 月, その人達（元ロシヤ軍人が多い） の協力とそしい資金を元手として飛行機の製作を目的 とする Sikorsky Aero-Engineering Corp. が誕生 し, 彼の航空事業の第 2 期一内容は第 1 期の延長一か スタートした、新会社の第一作 S-29-A（写真 8）は 中古のエンジン, タイヤ, 多くの代用部品を使い, 佊

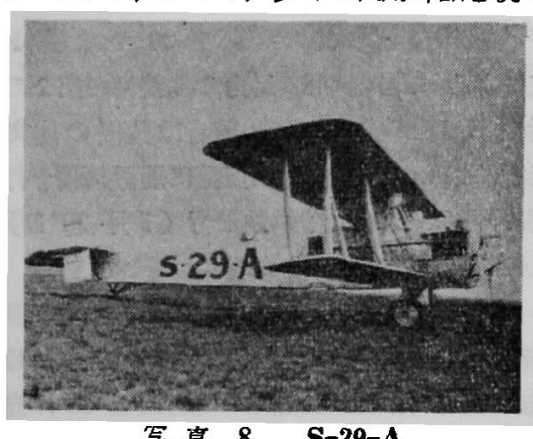

$$
\text { 写真 } 8 \text { S-29-A }
$$

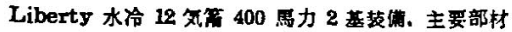

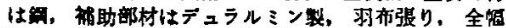

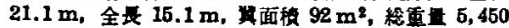
kg. 自贡 $8,625 \mathrm{~kg}$, 最高速 $180 \mathrm{~km} / \mathrm{h}$ ，巡航速 160 $\mathrm{km} / \mathrm{h}, 14$ 人の客原を有する㕕い客室を持つ。

の知識と全員の誠実な努力で不利な条件を克服しよ うやく 1924 年 4 月完成した. ロシヤの作曲家ピアニ ストRachmaninoff も工場を街れて，5,000ドルの拠 出と副社長就任を引受けた. 5 月飛行試験を行ったが, エンジンが中古のため出力不足で失敗, 新しいエンジ ンを稳換えて9月飛行試騟に成功した，本機は正規の 有料荷重をもって片発で飛び得る最初の米国製の双発 
機であり，本格的な旅客翰送の可能性を実証した最初 の飛行機でもった，後で旅客，貨物のチャータ一飛 行を業とした有名なパイロットRoscoe Turner に買 い取られた。

1925 年会社は拡張され, Sikorsky Manufacturing Corp. と改名した. 1925 26 年小形機 S-31, S-32， S-33 および双発の水陸両用機 S-34 が造られ， 航空会社に売られ，または試䤅研究に供された。この 頃までは彼自ら操綐して飛行試駼を行ってきた。

Raymond Orteig の㿽金の賭けられた大西洋無着陸 横断飛行を米仏の飛行家達が競ったのはその頃であっ た. Roosevelt Field を訪れたフランスの有名な René Fonckは同飛行場の一隅にあったシコルスキー工場て S-29-A を見，直ちにその向上大形化 1 機を発注，そ のS-35 は 1926 年 8 月完成した．横断飛行をあせる Fonck は，特に過荷重の飛行試験を充分行う間もなく 9月 21 日3 人の同乘者を乘せて Roosevelt Field か ら飛立つべく滑走中, 補助車輸が外れて離陸不能とな り，然料漏洩により発火， 2 人の同乗者は機とともに 嬅死した. 翌年春までに数組競争者が現われ失敗した。

S-35 の要目: Gnôme et Rhône Jupitor 485 馬力 3 基装備, 翼組は一葉半 3 べ, 翼 胴ともデュラルミン骨格羽布張り，自重 4, $400 \mathrm{~kg}$, 正規総重量 $9,000 \mathrm{~kg}$ ，過荷重総重量 $12,200 \mathrm{~kg}$, 全幅 $30.8 \mathrm{~m}$, 主翼面積 $102 \mathrm{~m}^{2}$, 性能は $3,600 \mathrm{~kg}$ の積載量をむって最高速 230 $\mathrm{km} / \mathrm{h}$ ，巡航速 $190 \mathrm{~km} / \mathrm{h} ， 1$ 分間上异力 240 m (一発停止て $75 \mathrm{~m}$ ).

1927 年双発小形水陸両用艇 S-36 および Fonck の注文による Jupitor 485 馬力 2 基荠備の第 2 の大西 洋横断機 S-37 が完成した. 前者は数機の注文を受 け，後者は Fonck が今度は慎重に飛行試駼を行って いる間に, Lindbergh の単独飛行 ( 5 月 20 日発, 5 月 21 日着) が成功して止んた。

しかし彼の実力はようやく世に認められるに至り， 1928 年に完成した 10 人乗り, P\&W Wasp 425 馬 力 2 基莣備の一葉半の水陸両用輸送艇 $\mathbf{S}-38$ は先ず米 海軍と PAA の注文を得, PAA の始めての旅客輸送 航空路に成功裡に就航し, 彼の第一の生涯の目標は具 体化の光明を認めるに至った．本機は数年にわたり航 空輸送会社, 米海軍, 事業会社, 外国政府, 個人等の 注文により合計 100 機以上造られ，会社の基礎も固 まった. 1928 年会社は盗本金 5 百万ドルの Sikorsky Aviation Corp. に改組され，彼は社長の地位 を退いて技術を主莘する副社長となった，翌年コネチ カット州の Stratford 海岸に新工場を建て, United Aircraft Corp.の一員となり，彼の地位は技術に専 念する技術部長に変り, 彼の事業は全く安定した。
次の S-39 は単発小形の高翼単葉水陸両用艇であっ た.

経験を皘んだ PAA は今まで世界て造られた何れよ りもずっと大形の輸送機の要求を持ち, Lindbergh 顧問として検討の後，シコルスキーの能力を信頼して その製作を発注した.ついに彼の咖い功の夢が寒 現する機会が到来した. 後に American Clipper と名 ぶられ，Clipper Series の先駆となった所の P \& W Hornet 575 馬力 4 基を装備した高翼単葉の水陸闭用 輸送艇 S-40（写真 9）の第 1 号機は 1931 年 8 月完 成した．性能は巡航速 $185 \mathrm{~km} / \mathrm{h}$ ，有料荷重 $1,500 \mathrm{~kg}$

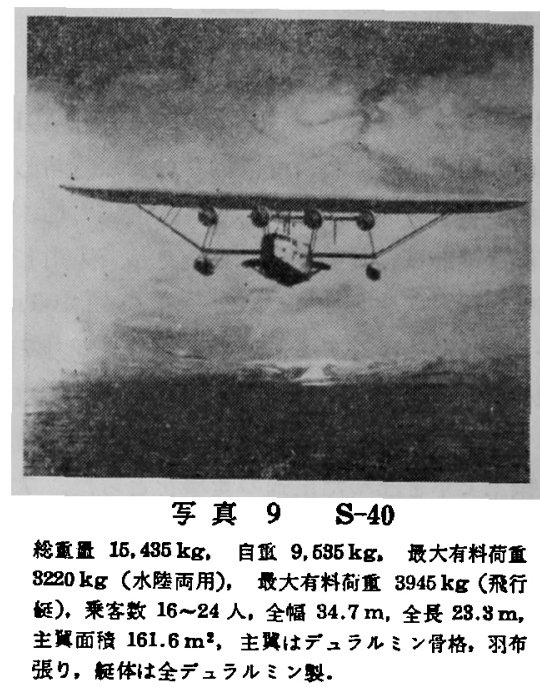

の時の航続距離 $1,600 \mathrm{~km}$, 有料荷重 $135 \mathrm{~kg}$ の時の航 続距離 $2,400 \mathrm{~km}$ ，これは世界の水华を大いに上回る ほどではなかったが，PAA の要求を满足し，架中， 水上の安定性操䋛性も良好であった。同年 11 月乗客 を乘せて処女飛行の後，マイアミからパナマに至る航 空路に就航して数年間使用された.

次の S-41 は双発の水陸両用輸送艇で，しみなむの であったＰAA は S-40より速度と航続力を大いに 上回る要求，すなわ乗員 4 6 名で有料荷重零の時 $48 \mathrm{~km} / \mathrm{h}$ の向い風に対して $4,000 \mathrm{~km}$ の航続力を持 つ 24-30 人乗り 4 発の水陸両用輸送艇を発注した. 彼は S-40 よりも断然高翼面荷重 $\left(150 \mathrm{~kg} / \mathrm{m}^{2}\right)$ を採 用し, 油圧作動のフラップをつけ, Hornet 性能向上 型を装備，始めてハミルトン・スタンダードの可変ピ ッチ・プロペラを採用し，4 基のエンジンを主翼前緑 に一列に配直し，従来のサイド・フロートと主翼斜支 柱を支える張出し翼を廃止し，艇体加ら直接斜支枉を 出した高翼単葉飛行艇 S-42（写真 10）を設計した。第 1 号機は 1933 末完成，翌年 8 月までに一定有料荷重 と一定距離に対する速度記録および一定有料荷重に対 する高度記録を合わせて 10 ケの記録を樹立した，巡 


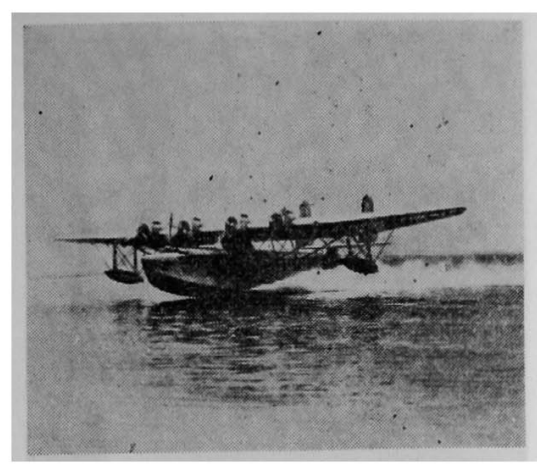

写基 $10 \quad \mathrm{~S}-42$

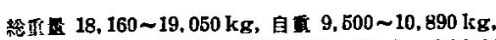
最大有料何的 $4,000 \mathrm{~kg}$, 乘各数 $24 \sim 32$ 人. 全阷 36

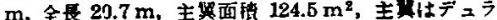
ルミン骨格, 後标加ら前方はデュラルミン张り。後方

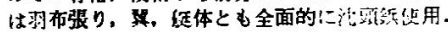

航速 $240 \mathrm{~km} / \mathrm{h}$, 乗員 5 名有料荷重 $3,850(3,610) \mathrm{kg}$ の時の航続距離 $1,600(1930) \mathrm{km}$ ，同しく有料荷重 $135 \mathrm{~kg}$ の時の航続距離 $5,000 \mathrm{~km}$, 燃料 1 ガロン当り の有料荷重トン・哩数は 4 以上で S-40 の約 3 倍であ った. 本機は 1934 年秋から米国・アルゼンチン間旅 客輸送に就航し, 1935 年 4 月サンフランシスコ・ホ ノルル間の無着陸横断に成功し, 同年サンフランシス コ・ニュージーランド間の旅客輸送に就航, 1937 年 ニューヨーク・イギリス間およびニューヨーク・パー ミューダ・ポルトガル間の旅客輸送に就航した.

こうして彼が生涯を賭けた第一の事業一大形蒙華な 飛行機の創造による定期旅客翰送の開拓一は完成に近 ふいた. 1912 年 9 月 Grand 号への着手から丁度満 25 年であった.

ちなみに陸上機では，近代式旅客輸送機の 先駆といわれる 10 人乘りの全金属製双発片 持低翼単苯のボーイング 247 が始めて UAL の空路に就航したのは1933 年4月，さらに 近代式に近ついた 14 人乘りのダブラス DC2 が始めて TWA の空路に就航したのは 1934 年 7 月のことであった。

次の S-43 は S-42 を半分にしたような双発の水陸 両用商用艇であった.

彼の第 2 期の完結編は，S-42 を一段と洗練近代化 した S-44 片持高翼単葉飛行艇（写真 11）であった. 本機は海軍の注文により哨找爆撃飛行艇 XPBS-1 と して 1937 年に試作され，第 2 次大戦終末まで海軍お よび AEAL の注文により量産され，主に大西洋横断 の旅客および貨物輸送に活躍した。

第二次大戦勃発とともに, U.A.C. 有下の Chance-Vought, Sikorsky 両 Div. は合併し $\tau$ Vought-Sikorsky Div.となり, Vought の小形軍用機の開発生産に力を集中, 約 3 年 間シコルスキーの任務はその管辖とへリコフ

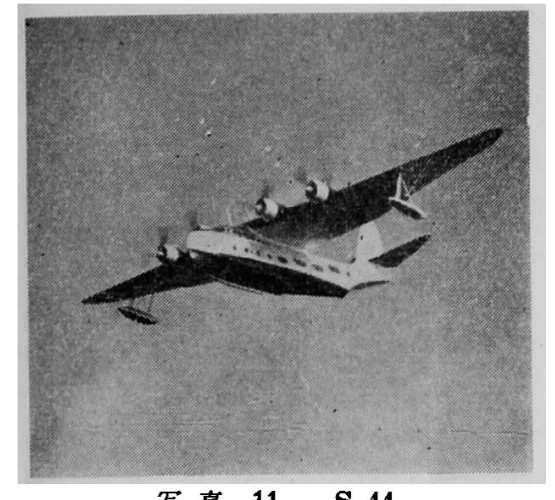

写真 $11 \mathrm{~S}-44$

エンジン P \& W 1,200 幜力 Twin-Wasp 4 琴,

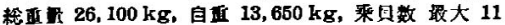
人. 莱各数 16 人 40人, 全颃 $37.8 \mathrm{~m}$, 全曼 24.2 $\mathrm{m}$, 最高速 $376 \mathrm{~km} / \mathrm{h}$, 巡航速 $260 \mathrm{~km} / \mathrm{h}$, 取大航秒 距䑾 $5,800 \mathrm{~km}$

タの研究開発との両方にまたがった。

\section{第 3 期}

1910 年以来彼の脳裡からヘリコプタが完全に消え たわけではなかった. 高能率, 大運搬力, 安全性と 快適性などを兼備する飛行機は大形に向い，かつ長い 離着陸深走路とますます不可分になってきた. 1938 年彼の申出てを容れて, United Aircraft Corp. はへ リコプタの開発に乗出すこととなり，彼の航空事業 の第3期はスタートした． 彼はすてに 1929 年に, 主回轱翼とそのトルクを打消す尾部補助回転翼を持 ち, 両回転翼の各羽㮛のピッチの同時操作 (collective pitch control), 主回䎐翼の各羽根の任意線通過時の ピッチの差動操作 (cyclic pitch control)，およびそ の方法機構を含むへリコプタの計画図を作り，1939 年秋に完成した彼のアメリカての最初のへリコプタ VS-300（写真 12,13）の特徽（スウォッシュ・プレート を含む）をほとんど全部網睢するような特許を 1931 年に出願していた. しかし実物の成功はドイッの H. Focke とフランスの Louis Breguet の多回転翼式へ リコプタによって先べんをつけられた.

VS-300 は始め主回転翼の cyclic pitch control で 䚣と横の操䋛を行うように設計されたが，飛行試験で うく行かず，一先ずトルク打消し用尾部補助回翼 と別に，胴体後部左右に各 1 組の上下軸補助回転翼を 付け加之,その同時的な collective pitch controlによ って緃の操坊をを, 差動的な collective pitch control によって横の操綐を行うような先輩の方式にならっ た. 彼自らテスト・パイロットとなって始めは地上慗 止状態から試験し，まずお定まりの振動に悩まされ， 次に安全な操縦方式の完成に 1 年以上かかったが， 本機とつぎの XR-4 て今日のヘリコプタの技術の基 本はすべて確立した. 1941 年 4 月にはアメリカで の耐空記録を作り， 5 月にはゴム製フロートを装着 


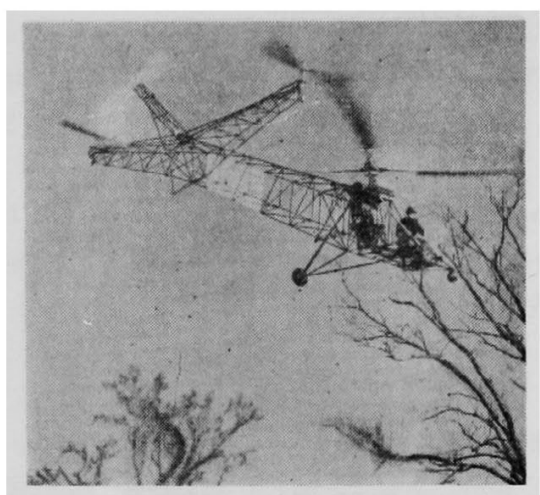

军真 12

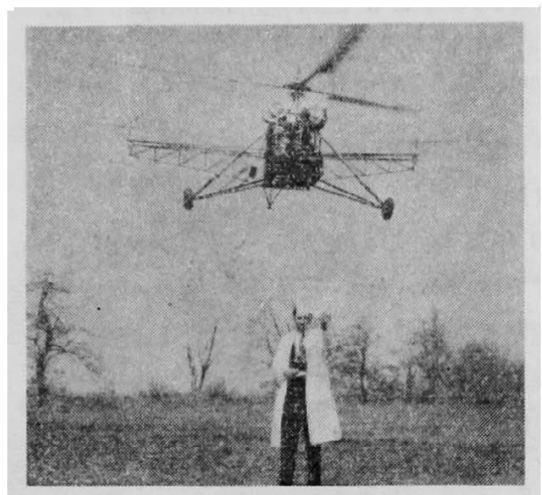

写真 13

VS-300 始め Lycoming 空冷 75 照力, 後て

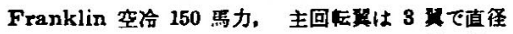

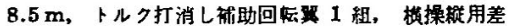

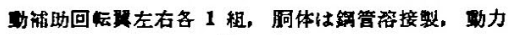
位些はVべルトおよび留車。

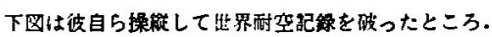

して地上水上に自由に発着し，かつ 1 時間 32 分 30 秒飛んで，1937 年の F.W. 61 による耐空記録（1 時間 20 分) を破った. 1942 年始めになって彼の初志 通り, 左右の補助回転翼を廃して, 主回転翼の cyclic pitch control のみで縦横の操綐が完全にできるよう になり，今日のすっきりした操綐方式が確立された。

1942 年陸空軍の注文により，本機を 2 夾の密䦥式 キャビン式とした VS-316 (陸軍名 XR-4)を1機納 スし, Sikorsky Div. は翌年付近の Bridgeport に移 って軍用商用へリコプタの開発生産に専念する眧知を 整え，VS-316 の改良形 YR-4 を陸空軍に少数，さ らにその改良型 R-4B をアメリカおよびイギリス海 軍に多数納入した。ヘリコプタの量産は，これが世界 最初である. 本機はWarner 185 馬カエンジンを装備 し, 主回転翼の直径 $11.6 \mathrm{~m}$, 総重量 $1,158 \mathrm{~kg}$, 胴体 は羽布で覆われていた。

これを発展させた R-5A はアメリカ海軍の 2 疟穓 测, 救難用ヘリコブタで, P \& W R-985 450 馬カエ

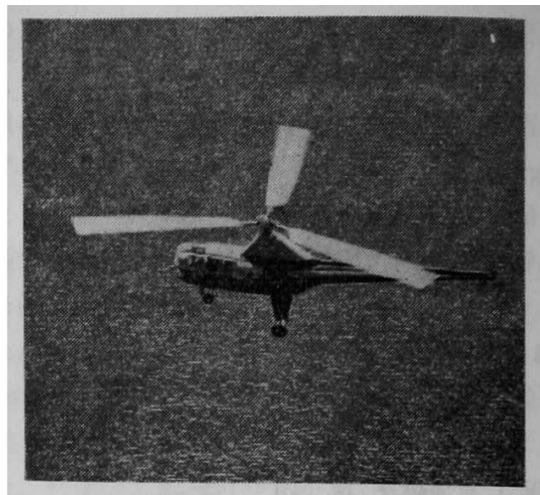

军真 $14 \quad$ S-51

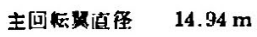

" 3

總正䄪 $2,500 \mathrm{~kg}$

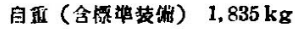

巡航速 (高度 $300 \mathrm{~m}$ ) $137 \mathrm{~km} / \mathrm{h}$

実用上昇限 $4.110 \mathrm{~m}$

ホバリンブ限度 $1,620 \mathrm{~m}$ (地面初果あり)

同上 $948 \mathrm{~m}("$ なし

ンジンを装備し, 総重量 $2,270 \mathrm{~kg} . \mathbf{R - 6 A}$ はアメリカ およびイギリス海軍に納めた 2 座観測，救難用へリコ プタで, Franklin または Lycoming 245 馬カエンシ ンを装備し, 総重量 $1,180 \mathrm{~kg}$, 約 230 機生産された。 第二次大戦終了後 R-5A を商用化した 4 人乘りの S 51 (写真 14）を造り，軍用型と合せて 220 機生産さ れ, 朝鮮事変にも活躍した. 1947 年以来母艦に㳟ま れ，また林野庁，郵政省，民間郵便飛行*, 山林の防虫， 種子秲き, 石油パイブ, 送電線の監視修理, 都市と避 暑地との直結その他の新用途の開拓者となった（“ロ スアンジェルス，シカゴおよびニューヨーク）．また ヘリコプタとして世界て始めて外国（イギリス）で イセンス生産された.

次の S-52 は R-6A に近い大きさ，同しェンジン

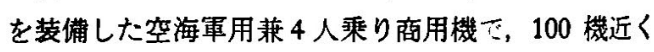
生産され，世界速度記録 $(208 \mathrm{~km} / \mathrm{h})$ を作った。

S-55（写真 15）は倈貣 2 名, 乘客 7 10人の商用 兼軍用多用途機として設計され，P\&W R-1340 600 馬力またはライト R-1300-3 800 馬カエンジンを装楮 し，始めて全金属製回轱翼を使用，1949 年 11 月初飛 行, 1960 年 1 月までに約 1,300 機生産され, 朝鲜事 変以来現在に至るまで陸海空軍用および商用に使用さ れている. 商用としては世界の 4 大定期航空会社 (へ ルギーの SABENA, ニューヨーク, ロスアンシェル スおよびシカゴ)およびカナダの Okanagan Groupに 採用され，イギリス，フランスおよび日本でライセン ス生産されている.

S-56（写真.16〜19）は始め海兵隊および陸軍の兵 貝輸送用として設計され，1953 年末初飛行，棈载量大 なる所から, 初めの目的の兵員, 兵器の輸送のほか, 

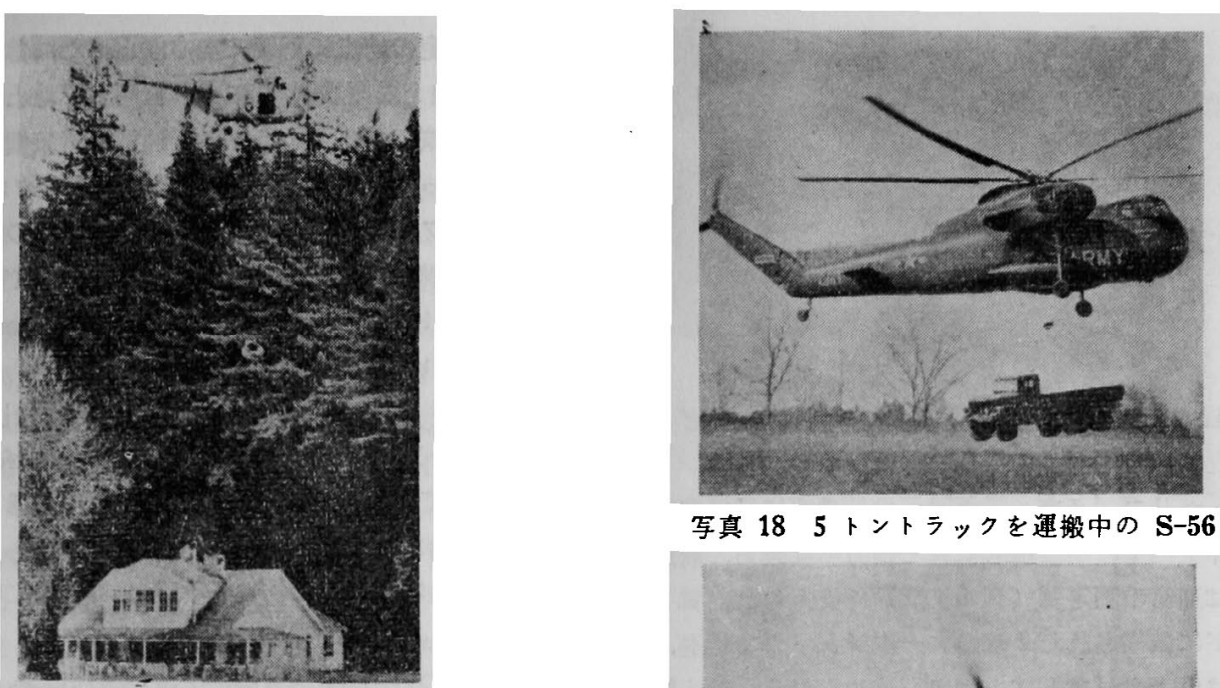

写真 185 トントラックを運搬中の S-56

写突 15 洪水の中で子を救出中の S-55

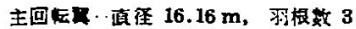

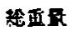
3.266 (3402) $\mathrm{ks}$

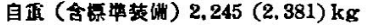
巡航速 $137(148) \mathrm{km} / \mathrm{h}$ 航却距霍 $643(578) \mathrm{km}$ 実用上型限 $3,200(3,230) \mathrm{m}$ ホバリング限度？（1,770） $\mathrm{m}$ (地面效果あり) 同上 $610(700) \mathrm{m}(" \|$ なし $)$

社括肠外は R-1340, 括弘内は $R-1300-3$ に 対忍.

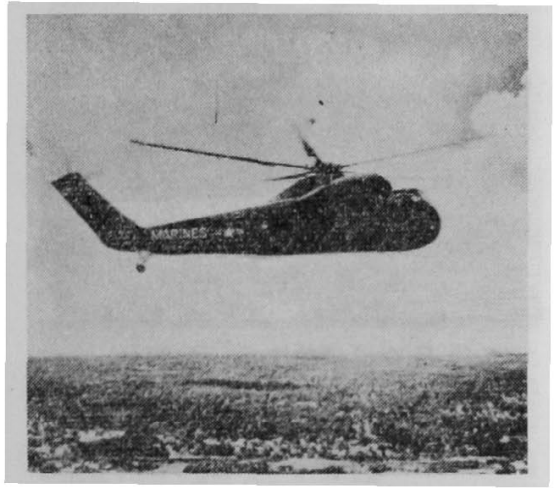

写真 $16 \quad$ S-56

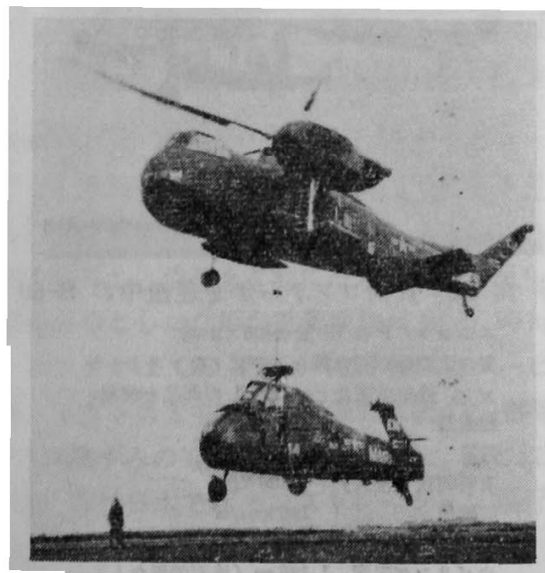

写真 17 S-58 を運掓中の S-56

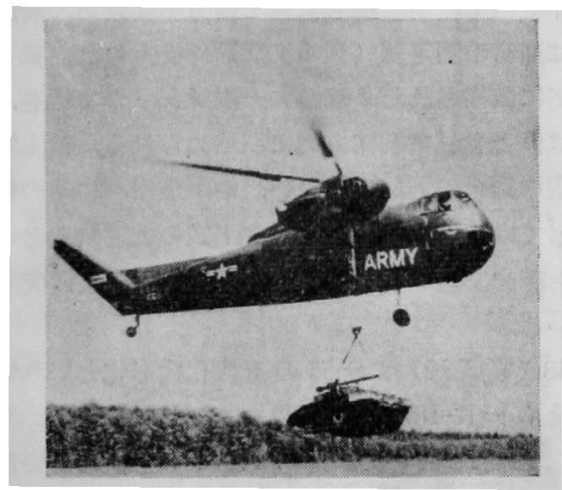

写真 19 戦車を連搬中の S-56

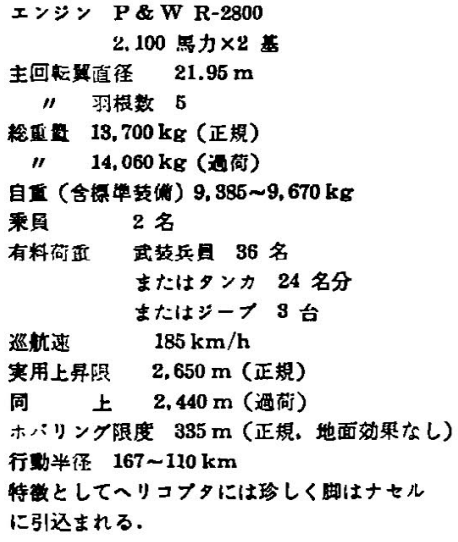

大形のサーチ・レーダーを装備して海軍の早期䇾牫機 とか，大重量物の近つきにくい場所への運搬などに も使われている。油圧操綎系統，独特の自動操祱装 置 (Automatic Stabilization Equipment, 略して ASE*)，電波高度計，トップラ・レーダー（対地速度 計), ウェザー兼対地レーダー，回転翼防氷装固等を 備え，ほとんど自動探絴，全天候化されている．今ま で海兵隊，陸軍および海軍の注文により約 150 機納入 され，引きつつき生産中である.

*本学会到 1959 年 12 月号 D. 9 の右第 40 行目の表現には不 富あり. 


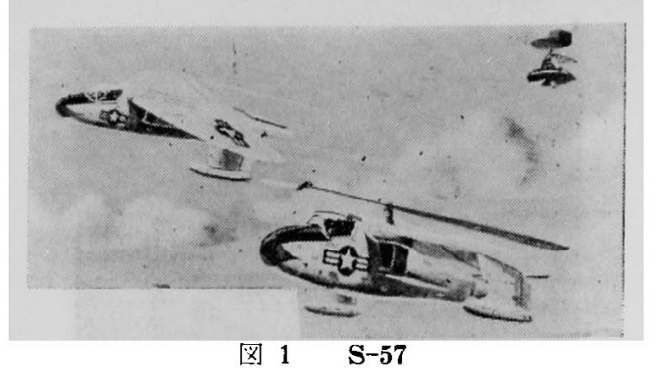

S-57（図 1）は空軍との契約で基礎計画と風と゚う訊 略を行い，目下引きつつき設計研究中の高速コンパウ ンド・ヘリコプタミ，離着陸その他華直に近い飛行中 は胴体上の 1 枚羽根単回転翼て掦力を受持ち, 前進飛 行中は通常の固定翼 (デルタ形)で支えられ，翼下の ポッドに装備された 2 基のターポシェットで推進, 回 転翼は停止されて胴体上侧に引込められる. 彼も離着 陸や空中停止の回数の少ない，中距離用，中速の輸送 機としては，理論的にコンパウド式の低運航費という 長所を認め, 近い将来実用の見込みを信して研究を進 めている.

S-58（写真 20）は S-55 の近代化大形化という性格 で, ライト R-1820 1, 525 馬カエンジンを装備, 乘員 2 名, 乗客 18 人または貨物 1.5 トンを積める商用兼 軍用多用途機である. 1954 年 3 月初飛行し，海軍，陸 軍および民間の注文により1960年 1 月までに約 1,200 機生産され，現往盛んに生座中である。機室は空気 調和され，S-56 と同様に ASE，全天候装備されてい るほか,レーダーを組入れた“Hover Coupler”およ び “対気航法装置 (Air Mass Navigation System)”

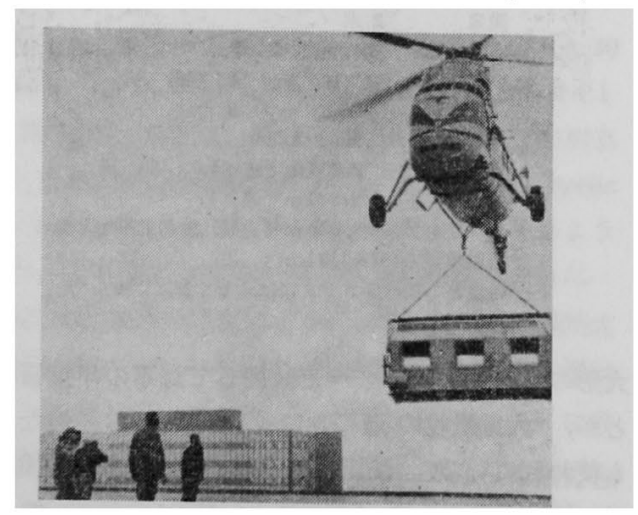

写真 20 エア・コンディション・セット を菿上に下ろしつつある S-58

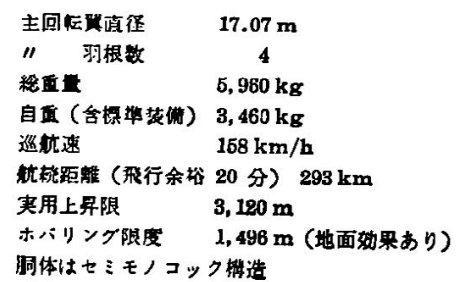

第 8 巻 第 78 号

により子定の地点に正確に空中停止または着陸可能, また“地上操綎装置”により低高度て地上員により 自由に操綐できるというような独特の新芰倩が持てる ようになっている. 旅客輸送用としてシカゴ航空二 ユーヨーク航空，および SABENA 航空の定期便に 1957 年以来就航し（ただしニューヨーク航空は 1958 年 V44B に切換え)，またカナダの Okanagan Group に採用され，高い稼動率を誇っている。

1957 年 Stratford に大きな分工場を開設して S-55 および S-56 の生産に充て, 1958 年 Stratford を本 工場としてここに技術部門や研究部門を包括した，彼 は 1957 年に長い間占めていた会社の青任ある地位を 勇退したが，今なおかくしゃくとして每日工場て設計 計画を行っている.

重量物の近づきにくい場所への運搬が，ヘリコプタ の用途の新分野として好望なことが S-56 の使用中に 認識されたので, 1959 年始めての専用クレーン・人 リコプタ S-60（写真 21,22）を世に問うべく試作し,
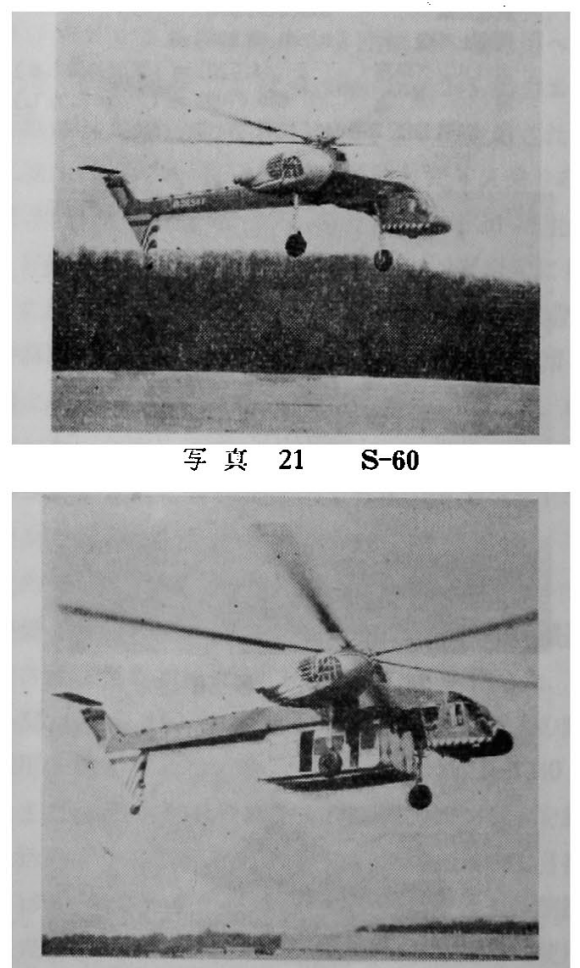

写真 22 貨物コンテーナを運般中の S-60

エンシン・P\& W R-2800×2 主および尾部回伝舆ならびにトランスミッシ

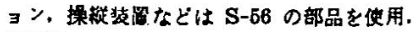

\begin{tabular}{|c|c|}
\hline 綏夏量 & $14,160 \mathrm{~kg}$ \\
\hline 自直 & $8,618 \mathrm{~kg}$ \\
\hline 梢料街酉（樶大） & $4,636 \mathrm{~kg}$ \\
\hline 巡机速 & $186 \mathrm{~km} / \mathrm{h}$ \\
\hline $\begin{array}{l}\text { 实用上开限 } \\
\text { ホパリンク゚限安 }\end{array}$ & $\begin{array}{l}3,290 \mathrm{~m} \\
1,125 \mathrm{~m} \text { (地面效果なし) }\end{array}$ \\
\hline
\end{tabular}

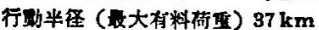


㕕簀囲の飛行試験によってその真価が立証された。

ガス・タービンの柽量小形，そのため機室外に装倩 し得ること, 巡航出力が最大出力に近いこと等の特徽 は，ヘリコプタ用エンジンとして好適であるが， 1954 年には早くも S-59（S-52 に Artouste II 400 馬力 ガス・タービン換装）を試作試験して素地を作った。

最初の生産タービン・ヘリコプタは海軍の水陸両用 の企天候対潜哨成攻整萧救難用の HSS-2（または海 兵隊の HS3S-1) て, GE T58-6 1050 乹馬力 (新型は $-81,250$ 軸馬力）タービンを 2 基装備し, 1959 年 3 月 初飛行，60年 5 月末まてに 15 機納入， 61 年末までに 合せて 79 機納入の契約がきまっている. 会社は海軍 と協力し，本機を用いて部品特に回転翼を含む動的部 品の今までに見ない徹底的な耐久試験を実施し，部品 の寿命の確認延長, 機体の整備時間の縮少, オーバホ 一ル間隔の延長, 稼動率の画期的向上を達成し, ヘリ コプタ運用経戌面に一大進少をむたらした。

HSS-2 の商用型が S-61（写真 23） そ，乗客収容 数は 25〜28, すてにシカココ航空，ロスアンジェルス航 空から発注されて生産中である.

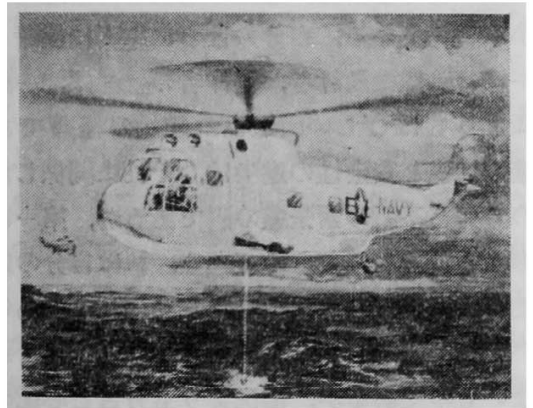

写真 23 対潜動中の $\mathrm{S}-61$

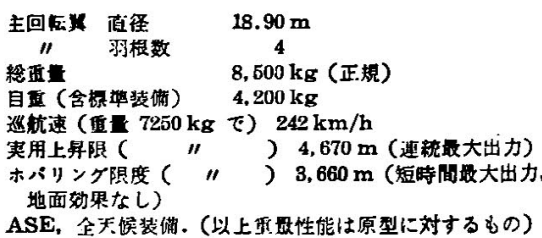

S-62（写真 24）は小形の新しいタービン・ヘリコ プタとして最初に試作（初飛行は 1958 年 5 月）され たものて，本機以降この会社はクレーン型以外水陸両 用型を採用し，他社もこれにならう傾向が見られる. 水陸両用型としたための重量増加は僅か $90 \mathrm{~kg}$ であ る. エンジンは GE T58-6 1050 軸馬カタービン，回 轱翼，トランスミッション，操就系統の一部等は S55 で試験ずみのけのを使用している，旅客収容数は 8〜12, 昨秋日本てデモンストレーション飛行の際富 士山頂に発着して注目をひいた. 米海軍,インド空軍, ロスアンジェルス航空等の注文により生産中である.

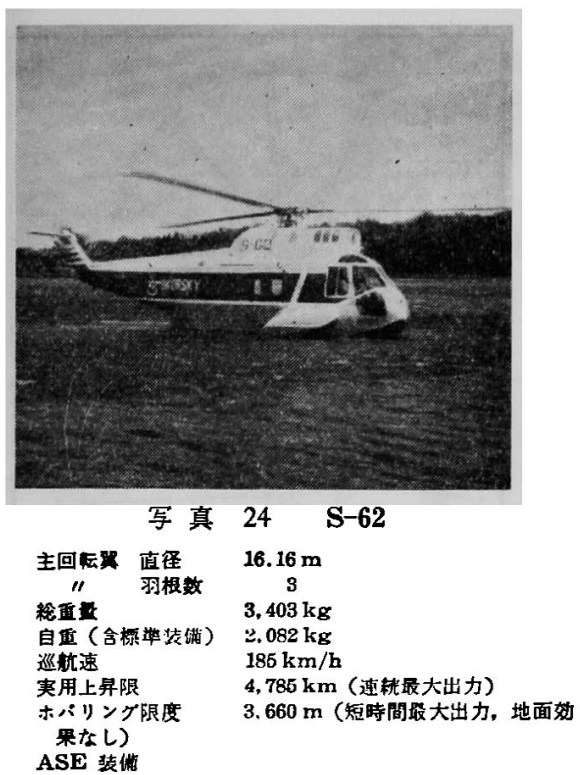

彼のクレーン・ヘリコプタに対する樊情は並々なら ぬものがあり，S-60 のタービン化 S-64（図 2）を会 社自前て具体化せんとしている.

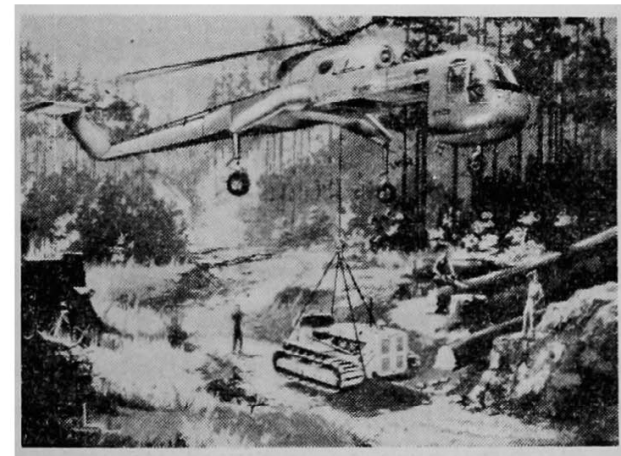

图 2 S-64

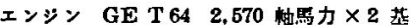
または P\&W J'T12 3,000蚰馬カメ 2 基 主回到算径 $21.95 \mathrm{~m}$

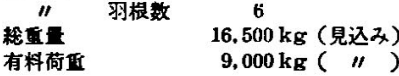

つづいて S-64を 2 倍以上にしたクレーン・ヘリコ プタの具体的設計（図 3）む進められている．回転翼 ハブの円形覆は空気抵抗減少の目的て，気密に造られ ている.ささらに総重量 100 トン, 有料荷重 40 トン内 外の単回轱翼式クレーン・ヘリコプタ DS-103 の計 画を持ち，具体化には 5 年の日子と 1.5 億ドルの経費 を要するという.

終りに各種の航空機に対する彼の考え方を要約す る.

彼はへリコプタの形式について，単回伝翼式がタン デム回転翼式に比して，棈造機裱上の簡単さ（特に SAS, ASE 薂備の場合顕著), 振動, 重量等の点で優 


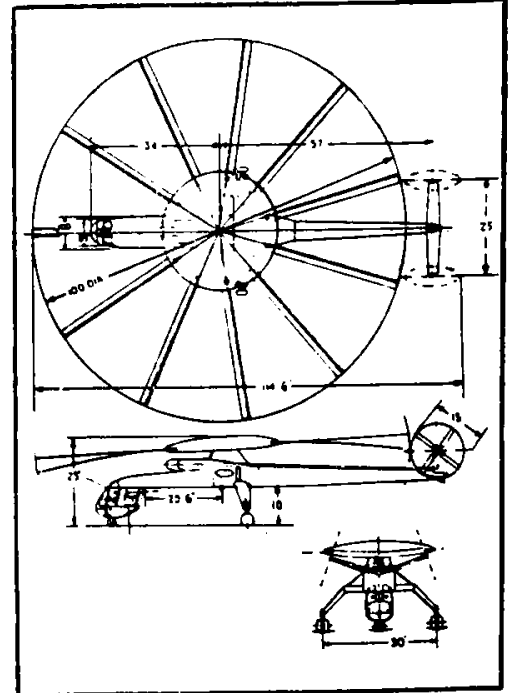

図 3 次のクレーン・ヘリコプタ エンジン P\&W JT 123.000 柚是力 X 4 惒 主回枟南直 $30.5 \mathrm{~m}$ 総正量 羽根数 $\quad 11$ 有料荷直 $19,500 \mathrm{~kg}$

れていると信している.この信念はヘリコブタ始ま って以来今までのほとんど全部の性能上の記録が単回 転翼式特にその半ばがシコルスキーのヘリコブタによ って作られてきた事実および彼のへリコプタの今日ま ての実綪によって，立証されているとはいえないたろ うか. そして単回転翼型式の大いさの制限（翼端速度 が音速に近接）は当分ないといえるとしている，筆者 個人として，彼の手がけたヘリコプタの無造作な外貌 形態には同調しかねるが，常に時流を技く粠想，機構， 装置, 部品のワークマンシップ等にはたた頭が下がる.

民需については，飛行機は高速大規模の交通機関と
して，また各種のへリコプタは短距離て，ごく面 のスペースしか与えられない場所間の交通機関とし て，両者はそれぞれ高い経済性をもって航空機の広い 用途を二分し，一方へリコプタ以外の各種のVTOL 機は効率と実用性の点で，限られた特殊の用途（軍 用は然り）しか近い将来は考えられないといってい る. 航空機の $2 つ の$ 分野において，常に先見性をもっ て時代をリードして来た彼のこの考え方は傾㯖すべき だと思う。

\section{結び}

彼の自叙伝の末尾に，生涯を設計開発に捷げた偉大 な技術者の言葉として心引かれる一節がある. それを 引用してこの稿の結びとする “良識ある設計者, 開 発技術者が自己の業縝から受ける满足感は，作物の種 を洔いた人が学作の結果と自分の目的が土から生成す るのを見る時の幸福な満足感以上ではないし，またそ れ以上であるべきですない．私の経醫からいえること は，有名な航空機の設計者の成功ははたから見れば単 純に大きな愉悦であるように見えるが，競争意欲と先 見行動から生ずる等苦，不安は，多くの場合名誉と成 功感に強い苦味を添え，過大の愉悦と自信感にひたる ことから防いでいる．自分の仕事に忠実に根深く携っ た第一線の航空機設計者，製作者の生涯は，一般の人 の生涯よりもはげしい山と谷の起伏の経過である. 航空機の性能と安全性の進歩は，それに関係した總て の人の労力と不断の緊張感の賜であるが，第一には责 任感の強い設計者に負うのである．私は自分の運命に 対して一般の人よりも余計感謝すべき理由があると信 ずる”と. 彼に比べれば私の程験などは全くとるに 足りないものであるか，愉悦よりも労苦と心配の方が 强さにおいても長さにおいてもずっと大きかった体娩 は，彼のこの言葉に深い共感を営えさせられる.

\section{外国の高速風洞}

\section{河 村 龍 馬*}

東大航空研究所では, 研究施設整備計面の一骤とし てかねてより超音速風洞および極超音速風洞建設案を 持っていたが，大学当局，文部省等関係方面の協力援 助によってその予算措置が講ぜられ，昭和 34 年度を 初年度として建設に着手する连びとなった．当初の計 画ては，测定部寸法は超音速風洞が $50 \times 50 \mathrm{~cm}$ (これ は後に装更されて $40 \times 40 \mathrm{~cm}$ となった), 極超音速風

*東京大学䡉空研究所
洞が $20 \times 20 \mathrm{~cm}$ ，いずれも Blow-Down 型である.わ れわれとしても一応の案は持っていたが，さて実際に 設計するとなると細かい点て困難に连着することも多 く，どうせ作るなら最良のものをという憼も出て来る しまた極めて限られた建設蹁（現在の見込みては一 切を含めて 2 億円弱) の枠内てたくさんの要求をどの ように満たして行くかという大問題むあって, 結局百 閳は一見に如かずという諺を文字どおり実行すること がこの際最も有効であろろということに研究所の方制 
が決定し，外国に風洞視察団を派遭することになっ た. 私が一応団長格になり，田中英稔助教授と風洞建 鹗工事を担当することとなった新三菱重工より高田茂 俊，山口富夫の両氏とが参加し，合計 4 名で欧米各国 の目ほしい所を讱回することになった，出発したのは 昭和 34 年9月 15 日で，それから年末に帰国するま て約 3 カ余りの間に，欧米各国でずい分たくさんの 風洞を調查してまわった，上記のように出張の目的が 非常にはっきりしている上に，われわれの風洞建設に 関する一応の具体案がすてににできておりり，また団員各 自の専門か適当に分散していて分担調査がし易かった 等，諸種の好条件に惠まれていたため，仕事は極めて 順調に進み，成果も大きかった，その反面，風洞調查 という当面の仕事に拘束され過ぎて民情視察にまで手 が回りかねたことは非常に残念に思われてならない。

今回のように，風洞調査という限られた目的をもっ た訪問は，訪問される側にとっては誠にアレンジや すいむのであるらしくフランスONERA を除いては何 処ても非常に好意的に最大の便宣をはかってくれた。 一方，時間的な制約もあって風洞関係以外の部門を視 宗見学する余裕はほとんどなかったのて，各国の航空 研究全般を公平な立場から跳めることは不可能てあっ たここではただ私達の見た事柄や接触した研究者, 技 術者および在外公館，商社の人達との討論から得られ た情報をたよりに見聞記らしきものを記すに止める.

最初の訪問国はイタリーであった．私達の目的から 言えば,この国には最初からあまり大きい期待は持っ ていなかった，外国旅行のウォームアップ程度の軽い 気持て訪問したものである.Guidonia 研究所が戦争で 溃减した現在ではイタリ一航空研究(特に実験方面)の 本山は Rome 大学にあると思われるが，幸か不幸か ローマには大学以外に見るべき所がたくさんあり過ぎ て，とうとう大学までは手が回りかねてしまった。 タリーで訪問したのは結局ナポリ大学とトリノ工科大 学てある，前者には若手の空気力学者 Napolitano 准 教授，後者には有名な Ferrari 教授がいる. 全般的に 言ってイタリーという国は日本と国情が非常によく似 ているような印象を受けたが，航空関係もまた天の例 外ではない，研究者の興味の対象も必ずしも先端的な むのばかりではなく，トリノ工大では㖶音速の研究を 謷心にやっているグループがいた．研究施設としては ナポリ大学にははとんど見るべきものはなかった. ト リノでは $40 \times 40 \mathrm{~cm}$ の超音速風洞を完成し現在整備 実験中であったが，この風洞はスイス・チューリッヒ 工科大学にあるのと全く同じものであった. Ackeret 教授がこの風洞について発表したのは 1935 年のウォ ルタ会議であったからトリノ工大では 20 年後に同
し風洞を作っていることになる、また，ここでは直经 $3 \mathrm{~m}$, 压力 3 気圧の低速風洞む建設中で,どうむこれら の風洞建設の狙い所がはっきりしないのでて点を Ferrari 教授に尋初て見た所彼は笑って答えなかった。 多分会社と大学との関係からこのような計画が進めら れていて，理論家である教授自身はあまり興味がない のだろうと察せられた。

イタリーの次にスイスに入って，チューリッヒエ科 大学と B. B. C, Zulzer の両会社を訪放た. 工科大学は Ackeret 教授の主莘する機械研究所だけを見たが，実 験設橵が非常によく整備され手入れが行き届いている のには感心させられた．盛沢山の設倩と研究成果とを 見せられたが，その多くは過去10年間に研究の行なわ れていたものて，現状は助手 5 人大学院学生 1 人しか いないので手不足であまり活潑な仕事は行なわれてい ないように見受けた。ここには，前記の $40 \times 40 \mathrm{~cm}$ 超 音速風洞と $2 \times 3 \mathrm{~m}$ の低速風洞とがあり，よく整備さ れているが主に学生実験に使用されている. Ackeret 教授自身は space flight や電磁流力に興味をむってい るが，実際には手不足てこの方面の研究は行なわれて いない. 二つの会社については，世界各所からの註文 による大型軸流機がズラリと並んだ壮観さに眼を蒘わ れた以外，あまり得るところはなかった。

フランスではパリとモダーンとにONERAを訲問し たが，いずれも風洞施設等は見せて鿓えず，私達の筫 問に対して関係者から口頭で返答あるいは討論を得た だけであったのは牫念たった。出発前のアレンジの不 手際もあったかも知れないが，ここだけが例外だった ところから見てやはりフランスの特殊事情によるもの と思われる，今後ここを訪問される方は半年くらい前 から公式のルートを通して十分に交涉し，先方加らの 返事が不明確な際はむしろ訪問を取り止めることをお 勧めしたい：なお，このような事は格別日本人に対し てだけでなく，外国人一般に対して同しであることを 付言しておく。

ヨーロッパ大陸では，上記各国の他ドイッとオラン ダを訪問した. ドイツで最初に訪ねたのはミュンヘン の T. H. (E. Schmidt 教授)であったが,ここには小さ い超音速風洞の他は見るべきのむなかった.たた有 名なピール祭を見物てきたのは大きい収檴であった。 アーヘンの T.H. は今回の旅行の主目的地の一つで, Naumann 教授の案内て超音速風洞を丁罣に見せて黄 い，非常に有用な資料が得られた。㝊 $30 \times 30 \mathrm{~cm}$, マッ八数 5 の風洞の組立てが完了したところておった が，この風洞は空気遏度を $560^{\circ} \mathrm{C}$ ま高める加熱装 国を持っており，設計上もいろいろ新しい考案を取り 入れてあって，私達には非常に興味があった.ここで 
Oswatitsch 教授とも整く話をしたが，現在でもやはり 要音速関係の研究をしているとのことであった．ドイ ツではこの他ミュールハイムの D. V.L., ゲッチンゲ ン大学, ブランシュワイヒの T.H. および D.F.L. を訪問したが，D.F.L.の翼列実験を除いては研究活 動はあまり活潑とも思われなかった。ここには歴史的 価値のある Prandtl-Busemann 超音速風洞があり，今 で教育用に使われていた．総してドイツの航空研究 はその国情を反映してまたその方向を見出しかねてい る状態で,この意味では日本より一歩立ち遅れている ような感しがした，研究者は口を揃えて航空国策の未 決定をこぼしていた．D.V.L.ではケルン近郊に綜合 的航空研究施設の建設索計画しているか，程費の都合 で実施のピッチは極めて遅いようである．完成の暁に はわか国航技研と同程度の規模となろう.これと併行 して,アーヘン, ゲッチンゲン等ボスの所在地にそれ ぞれ特街ある研究施設を作りつつある.オランダでは アムステルダム近郊の国立航空研究所(N. L. L.)を訪 問したが、ここはオランダという国に何故この上うな 研究所が必要なのかと疑いたくなるほど立派なもので あった. 空力関係では本格的な遷音速風洞と $2 \mathrm{~m}$ 低 速風洞とが運枟中で，その他 Blow-Down 型の超音速 風洞 $2 つ(27 \mathrm{~cm}$ 角, マッ八数 $6 ; 1.2 \mathrm{~m}$ 角, マッ八数 4）をスイスの会社と契約して現在建設中である.こ れらは眝気槽内に蓄熱器を持ち, そのうえ蒸気加熱装 置を有し、ノズルは throat-blockと flexible plate を併 用するものである. 欧洲大陸で程済，政治等すべて の面において各国の連合による共同体を組織する方向 に進んでいることは周知の事実であるが，航空関係て む同様で, 前記のケルン近郊に建設中のドイッの研究 所でも邉音速風洞は N. L. L. のものを使用すること にして計画からはふくく予定とのことであった。

ドイツで欧洲大陸を終って次にスエーデンとイギリ スをまわった：スエーデンで訪問したのは F.F.A. と K. T. H. である.この国は現在イギリスに次ぐ空 軍国だあって，航技研に相当する F.F.A. の研究 活動は相当活潑であるように見受けたここには勿論 普通風洞もあるが，その特色は，ストックホルム市の 基盤となっている丈夫な岩盤を利用して地下に 11， $000 \mathrm{~m}^{3}$ の真空槽を作り，これを使って大小各種の要音 速，超音速吸込風洞を運転していることである，その 中最大のものは $1 \mathrm{~m}$ 角の遥音速風洞である. また， 直径 $20 \mathrm{~cm}$, マッ八数 7.5 の極超音速風洞（16 気圧 の貯気槽から吹出して真空槽に吸込ませる）を整備中 でり，近い将来の計画として直径 $50 \mathrm{~cm} ，$ マッ八数 10 のものを考えているとのことである．F.F.A. て 特に感心させられた点は，実に完儬した電子工学部阿
と模型工場とを俌えていて，ストレン・ゲーシ・・゙ラン ス，記録計，压力測定蔐置，模型，ノズル等を自家製 作するばかりでなく，たえずこれらの精度向上に努力 していることであった.ここでは主に超音速の専門家 G. Drougge 博士が案内役をしてくれたか，その話に よればここでは遷音速, 超音速の研究は盛んであるが 極超音速や䉓磁流力等はほんの序の口しかやっていな いとのことでった，K. T.H. の航空は船舶工学と 一舶の教室て, S. Lutander 教授の担当する航空学と 最近 F.F.A. から移った S. Berndt 教授の受持つ気 体力学とに分れている. 空力の施設としては $22 \mathrm{~cm}$ 角 の超音速風洞 (Blow-Down 型), $33 \mathrm{~cm}$ 角誘導式高 速風洞， $2 \mathrm{~m}$ 角普通風洞等丁度東大航研にあるくらい のものが揃っており， $20 \mathrm{~cm}$ 直径の極超音速風洞む計 渎中である.これらはすへてて航空学講座の方に所属し ていて，気体力学の方は設備は零である. Berndt 教 投の意見では shock tube や gun tunnel を計面中て あるが，折角 F.F.A. から大学に来たのだから当分 ノンビリやりたいと思うとのことであった。

ストックホルムからコペンハーゲンを経由してロン ドンに入り，最初に N.P.L. を訪問した，総選挙て 保守党が勝利を博した直後て政府機関に若干の組鐵変 更があり，N.P. L. も 3 日程前に Ministry of Supply から Dept. of Sci. \& Indust. Research 一所管換えにな ったばかりのところであった，総人員 1,100 人くらい の規模で, 航空関係では低速, 高速の 2 つから成る空気 力学部がありその総勢は 150 人くらいとのことてある 低速の方は Punkhurst 博士, 高速は. Holder 博士が担 当している.私達は主に高速関係を見てまわったが， ここの特色はあまり大型の風洞を持たず（高々 $50 \mathrm{~cm}$ 程度), 超音速風洞にはすべて固定ノズルを使い,また 誘導式風洞でマッ八数 1.8 くらいまで超音速を得て いることなどである，遷音速から超音速領域の実駼研 究が盛んで，極超音速関保は小型の 2 段膜 shock tube の実験を行なっている他本格的な風洞を 1 年後に完成 する予定でる. イギリスでは，大学は教育の負担が 大きくこの種の実験研究はあまり活潑でないようで, N.P. L. が丁度日本の航研に相当するような感して ある. たたここははやり役所で，研にくらぺて個人 色が薄く組織的であるように見られた． N.P.L.の 次には R.A.E. を見学した：ここは本格的要音速屈 洞のあるファーンボロと8吹超音速風洞のあるべッド フォードの 2 カ所に分かれている. ファーンボロては 7 时極超音速風洞の調查を行なったが，これは 250 気 壬のボンべ式気蓄器から加熱器, 測定部を通して真空 榑に放出する形式のもので，マッ八数は最高 9.0、こ の時の温度 $680^{\circ} \mathrm{C}$ である. 蓝熱材には 2 ton の耐熱俭 
を使い,ノズルは 2 次元でシリカを朽料としている. 特色としては急開門茾を加熱器の下流においているこ とで,この方式は熱や空気の損失を避けるためには有 利てあるが，高温のために并の作動に困難があるよう でここではその対策として弁を外側からも熟してバ ランスをとる方法をとっていた．この風洞もまだ本格 的な実験を行ならところまでは行っていないようであ った.ベッドフォードのR.A.E.では，すでに文献に む発表されている 8 叹超音速風洞(マッ八数 2.8)かi運 枟中の他，現在高超音速風洞索建設中てある。これは 测定部寸法 $4 \times 3$ 呎, マッ八数 $2.5 \sim 5.0$, 温度 $40 \sim 150$ ${ }^{\circ} \mathrm{C}$ で, 主送風機 88,000 馬力, 補助送風機 4,500馬 力という規模のもので，明かにミサイル研究用であ る.ここの R.A.E. の近所に A.R.A.があり, $8 \times 9$ 吹の遥音速風洞と $2 \frac{1}{4}$ 吹角の超音速風洞（マッ八数 1.4 4.0)とが運枟中であるが詳しくは他の文献にあ るから省略する.ロンドン沅在中に Imperial College に Squire 教授, Cambridge 大学に Mair 教授孛訪 初研究室を見せて筫った。いずれも風洞は大したもの はなかったが, Imp. Col. ては gun tunnel (shock tube tunnel であるが contact surfaceの所をナイロン 製のピストンで置き換えたもの，持続時間が長くなる のが特徴)の実騟が興味深かった，Cambridge 大学 では，工学部の新しい建物に実に立派に整備された学 生教育用の実験設借と, Taylor 先生で有名な Cavendish Lab. の狭く薄暗い実験室の乱雑さとの対照には 噚然とさせられた．ロンドンの次にはマンチェスター に移動して，その近郊にある A.V. Roe と English Electric の $2 つ の$ 会社の風洞を調查した. E. E. 社は日 本の日立製作所のような会社て製品の種類は多方面に わたり他社を合併吸収してイキりス本国各地にたくさ んの工場をむつ有力会社である. 風洞にしても，R.A. E. を利用するだけでは不十分としてA. R.A.にも参加 しないで独自に建設したもので現在 4 吹風洞（マッハ 数 $0.3 \sim 4.5$ の测定部の下流にも 31 万有孔壁遥音速 洌定部をひつ）が完成運転中で，別に同し貯気槽を利 用する 18 吋角の超音速風洞 (マッ八数 1.6 6.0)を 建設中である. 前者は有人飛行機用，後者は G.M. 用と目的むはっきりと分けられている. 貯気榑は4 本 のシリンダーから成っていて総容量は $11,000 \mathrm{ft}^{3}$, 圧力 40 気圧で内部に波板と平板とを組合わせたマトリッ クス型の蓄熱器 30 ton が入れてある. また， 4 呎風 洞には卉が 1 つかなく，これで䋨切，急開閉，王力制 御の 3 作用を行なわせている．最初はこの方式が一番 経斉的であると考えて採用したが，実際の作動がなか なかうまく行かず苦労して結局高いむのについたと苦 笑していた. そのためか 18 时風洞ては締切弁と急開

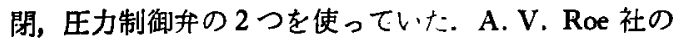
風洞は E. E. 社と同様に Blow-Down 型で, $30 \times 27$ 时, マッ八数 1.6 3.5 の超音速風洞である. 特徽は 球型眝気槽（直径 40 吹, 扗力 $100 \mathrm{psi}$ ）に䔳熱材とし てスクラップ 100 ton を詰込んだ点である. 雨社の風 洞は2つとも全く実用を主として作られたものて，建 設费の切下げには大いに努力した模様であるが，貯気 槽だけをくらへててもこれだけの対照的な相違があり， 両社ともそれぞれ自社のものか湕設費最低であると主 張する始末て全く判断に困った. 眝気槽の中にスクラ ップやアキ鹳を入れると，何年か後に再び水王試験を やったり内面検查をする時その出し入れに困ることが 予想されるが，この点について A.V. Roe 社では， そのような検查は保険会社に任せてあるから自分の方 には貫任はないとのことであった. 実際上建設後 2 力 年たったが，スクラップが銷びたり破壊したりする様 子は全然見受けられないとのことであった。

ヨーロッパを終ってカナダに渡り，オタワの Nat.

Aeron. Establishment とトロントの Inst. of Aerophysics (トロント大学の航空学科)とを訪問した。 N.A.E. では $5 \times 5$ 吹の Blow-Down 型超音速風洞 （マッ八数 1.0〜4.5）を本年末までに完成すへく建設 中で，そのために数年前より $1 / 12$ 模型を作って十 分の予備研究を行なっている. 弁機棈, ノズル, 乱 流によるノイズその他実に詳細な研究を行なってい て私達ためにも有用な参考凟料がたくさん得られた。

N.A.E.の研究としてはその他は空中車や寒冷地飛行 対策等が目ぼしいもので，全般的にあまり活潑とは言 えない. 空力部長 Templin 氏の意見によれば, カナ ダは地理的にも米ソ間の Ballistic Range に相当し, 航空工業も英国系資本のものが多いためなかなか研究 開発関係は活潑にならないとのことであった. LTIA は大学の主構内とは踓れた郊外にあり G. N.Patterson 教授に事いられて shock tube, 電磁空力, 稀薄気体 等新しい空気力学の実験研究を菓中的に行なってい る. shock tube は小型のむの 3〜4 基が動いていた が, shock Mach の最大は 30 くらいまで得られてい るようである. 测定畒は薄膜温度計, 干涉計, 圧力 ピック・アップ, 回転カメラの他 electron beam に よる密度の测定が目新しかった，直佳 $50 \mathrm{~cm}$ の円筒 型具空槽を使った稀薄気体風洞は Cryo ポンプとプラ ズマ・ジェットを備えるように改装中であった。

最後にアメリカに入り，ここて最も多くの時間を過 したわけであるが，見せて鿓ったものの中にはあまり 巨大過ぎてかえってわれわれの参考となり難いものむ 多く，またこの国には既に多くの人が訪問してょく紹 介もされているから，適当に省略して記すことにする. 
最初に訪れたのはバッファローのコーネル航空研究所 でここには富士重エの FJ1 の試験をした大きい選 音速風洞がある. 5 年前に訪問した時は遷音速風洞に 改装したばかりで, 秘密めかして詳しいことは教えて くれなかったが，今度は大分侎子が変わって何でも話 してくれた．最近では委託の仕事が減って飯の食い 上げになりそうだとこぼしていた。 また，補助送風機 の馬力が予定の半分くらいしか必要でなかったと言 っていたか，もう少し早くこのことがわかっていたら 航技研の風洞にも役に立ったかも知れないと思った。 ここで注目すべきことは，極超音速風洞の代わりに Herzberg の開発した shock tunnel の大型のものを使 って開発の仕事を始めていることであった。数ミリ秒 の持続時間で十分の測定ができるが，ただ一番困るの は設計者がこのような短時間内の測定結果を頭から信 用しないことだと担当者がこぼしていたのは刋象深か った. ハッファローから南に飛んでトラホマの A.E. D.C. を訪ねた. ここは空軍の開発機関で, 推進, 気 体力学, エンジン試験の 3 部に分かれており，そのお のおのが大小各種の風洞を運転している. 最大のもの は 16 呎角の超音速風洞で, 主送風機 21 万 6 千馬力, 補助送風機 9 万馬力, 排気送風機 9 万馬力という巨 大なもので, 内部で推力 5 ton のロケットまで実験が でるとのことである. その他マッ八数 8 まての極超 音速風洞がいつかあり，また值径 $50 \mathrm{~cm} ， マ ッ 八$ 数 20 の hot shotによって開発的な研究も行ないつつ ある.とに角規模が大きすぎて対手にしか权る感じが した. N.A.S.A. のラングレ一研究所も規模の大き いことは A. E. D.C. に近いが，その性格上研究の方 向がより基磷的であるような印象を受けたここには 極超音速風洞の草分けである 11 时風洞がある. 現在 ては大分改造されて加熱器も文献に出ているものとは 変わってニクロム管を電気加熱する方式となり，マッ 八数も最高 10 である. その他 31 吋角，マッ八数 20 の風洞を建設中である.ここで初めてペブル・ヒー ターを見ることができた．筒の中に直径 $5 \sim 10 \mathrm{~mm}$ 程度の酸化シルコニウムの球をたくさん詀め, 上から プロパンのバーナーて熱して, $4,000^{\circ} \mathrm{F}$ 程度まで温度
を上げ，これを通して空気を加熱する方式である。こ れはブルックリンエ科大学の Ferri 教授の創めたも ので，温度によってペブルの材料にアルミナあるいは 他のセラミックを使う. 今のところ風洞としてはこの 方式によって最も高温が得られるが，実在気体协果の 現われる所まで温度を高められるかどうかが今後の大 きい課題である．極超音速風洞のノズルは咽喉部の面 䧆が非常に小さくなる上に高温になるため，璉々の愦 差を避けるために軸対称ノズルを使らのが望ましい， しかし微妙な曲楾をもった長い軸対称ノズルの工作は 大変な仕事で，少し大型のものになるとこれを一体で 作ることは困難である. しかし近年一米人が electroforming という方法を発見して精度のよいノズルを作 れるようになった.これは，雄型を回転させながらた ん念にその上にメッキして行く方法で, ワシントン 近郊の N.O.L. が最初にこのノズルを採用していい 成績をあげた。たた発見者が今たにその技術を公開せ ず自宅のプールで作り多額の製作費を要求し，さりと て他の者が真似をしたのでは決してうまく行かないと いうことで困っているょうである.アメリカでは上記 の他東西両岸の主な所は大てい訪問して步いたが， あ まり紙面の余裕もなくなったのでこの辺で止める.

今回の旅行で得られた目象で，アメリカとそれ以 外の西欧諸国とでは空気力学の実験施設という面から 見ると格段の差があるように思われる．極超音速風洞 にしても，風洞として完成し実用に使われているもの はアメリカ以外にはないと異って差支えない：他の国 では建設中か整備中か計画中である. またアメリカで は新しい分野における開拓の競争と施設の巨大化とが 極端に盛んで，その反面遷音速や超音速の研究は欧洲 各国の方がむしろ盛んである. 特にアメリカでは自由 競争が激し過ぎて設備や人材の重襩，別の言葉で言え ば無駄が多いことが目についた.これはある意味では 非常にいいことて，これを無駅というのはわれわれ日 本人の䨘之根性かむ知れないか，一面ロケット・オリ ンピックでソ連に勝を骞った原因もこの辺にあるかむ 知れないという感じ樑くした。

\section{抄 録 (続き)}

(184 頁より桃く)

ーリ, アイオワ諸州では, トルネードーとか雷雨, 䨠 などのような局部的な強いあらしを，適当な㮔まきに よって，おだやかな降水，よわいあらしに轱換するこ とが出来るかどうかの检副を初みる. 今のところ，ま だ手はつけていないが大規模な天候および気候変換の

可能性も検討する.

アメリカ科学財団は 1958 年 7 月から 1959 年末む ての 18 カ月間に研究費 160 万ドルを支出した．その 使い途は（1）野外実餄による研究，(2) 実験的研究， （3）統計的研究，(4) 研究発表集会の4つにあてられ た.

(荒川秀俊) 